\title{
A Carcinicultura do Nordeste Brasileiro e sua Inserção em Cadeias Globais de Produção: foco nos APLs do Ceará
}

\author{
Elda Fontinele Tahim ${ }^{1}$ e Inácio Fernandes de Araújo Junior ${ }^{2}$
}

Resumo: O artigo faz uma análise da forma de inserção da carcinicultura do Nordeste, em particular dos Arranjos Produtivos Locais - APLs de cultivo de camarão do estado do Ceará, em cadeias globais de produção, bem como sua estrutura de governança. Isto porque os sistemas de cultivo destes crustáceos se concentram no Nordeste, sendo, na atualidade, o Ceará o maior produtor do Brasil na forma cultivado, expressando, ao longo de suas bacias hidrográficas, dois APLs bem característicos (litorais leste e oeste), que estiveram intensamente inseridos em mercado internacional por meio de cadeias globais de produção. O estudo teve por base um levantamento de dados secundários e entrevistas junto aos gestores e proprietários das empresas e outros agentes dos APLs. As principais evidências da pesquisa apontam que a inserção das empresas dos APLs ainda ocorre de forma dependente dos grandes compradores internacionais e os benefícios gerados, em grande parte, são apropriados fora da esfera produtiva, influenciando as capacitações produtivas e inovativas dos produtores locais. A estrutura de coordenação é verticalizada, demonstrado certo grau de assimetria nas relações de poder entre diferentes segmentos de agentes, sendo os principais estágios da cadeia de valor, em parte, controlados por agentes externos aos arranjos.

Palavras-chaves: carcinicultura, Arranjos Produtivos Locais, cadeias globais de produção, formas de governança.

Abstract: The article makes an analysis of the way of insertion of the shrimp culture in the Northeast Brazil, in particular Local Productive Arrangements (LPA) of shrimp cultivation in the Ceará State, in global production chains and its governance structure because the_cultivation systems of these cretaceous are concentrated in the Northeast, and, currently, Ceara is the largest producer of cultured shrimp from Brazil and presents along of its water parting there are two characteristic LPAs (east coast and west coast) that were

1. Doutora em Economia pela Universidade Federal do Rio de Janeiro (UFRJ). Professora do Instituto Centro de Ensino Tecnológico do Ceará e do Mestrado em Administração da Universidade Estadual do Ceará (UECE). Fortaleza (CE). E-mail: fontineletahim@gmail.com

2. Doutorando em Economia na Universidade Federal de Juiz de Fora (UFJF). Juiz de Fora (MG). E-mail: inaciofaj@gmail.com 
strongly inserted in the international market through global production chains. The study was based on a survey of secondary data and interviews with the companies' managers, owners and other LPAs' agents. Main findings of the research show that the insertion of LPAs of companies still happens quite dependent on large international buyers, and the benefits generated, in large part, are appropriated out of the productive sphere, influencing the productive and innovative capabilities of local producers. The coordination structure is vertical, with some asymmetry degree in power relations between different segments of agents, being the main stages of the value chain controlled, in part, by external agents to arrangements.

Key-words: shrimp culture, Local Productive Arrangements, global production chains, government ways.

Classificação JEL: F10, O13, Q17, R10.

\section{Introdução}

Uma questão que vem recebendo bastante atenção nas abordagens sobre sistemas e arranjos produtivos locais (APLs) é a forma de inserção dessas estruturas produtivas em redes globais de comercialização. Esta, com efeito, pode influenciar intensamente a coordenação das atividades ao longo das cadeias, as configurações em termos de relação de poder de tais estruturas, suas capacidades produtivas e inovativas, bem como suas competitividades.

Neste contexto, autores como Schmitz (2005), Schmitz e Nadvi (1999) e Humphrey e Schmitz $(2000,2004)$ argumentam que o desenvolvimento de quaisquer aglomerações produtivas dependerá, não só da sua estrutura e dinâmica interna - e sua interação com outros agentes - mas, também, de sua posição na cadeia global de produção. Isto significa que, embora os vínculos de cooperação sejam importantes, são insuficientes para alavancar o dinamismo, a competitividade e a expansão desses arranjos. Tal óptica está relacionada à ideia de que a intensificação de competitividade em decorrência da globalização conduz à integração de produtores locais, em países menos desenvolvidos, a cadeias globais de produção. Neste caso, a inserção de APL em cadeias globais de produção passou a influenciar o equilíbrio entre forças globais e locais na definição de estra- tégia de desenvolvimento dessas estruturas produtivas (VARGAS, 2001).

Garcia et al. (2004) ressaltam que os arranjos produtivos locais, quando inseridos em cadeias globais de valor, têm a possibilidade de proporcionar vantagens, não só às empresas locais, como também a grandes compradores internacionais, que encontram nestes APLs produtores com elevada capacidade competitiva. Esses fatos trouxeram à tona a questão de quem está se apropriando dos benefícios resultantes dessa inserção, se agentes locais ou globais, tornando-se, portanto, ponto fundamental na compreensão das estratégias inovativas e competitivas dos APLs, em especial, dos APLs de carcinicultura do Nordeste brasileiro.

A carcinicultura é uma atividade que se expande no Nordeste brasileiro, especialmente no Rio Grande do Norte e no Ceará, onde se verifica a presença bem característica de APL, na visão da RedeSist ${ }^{3}$, pela grande concentração de pequenas e médias empresas ao longo de suas principais bacias hidrográficas. Tais empresas

3. Rede de Pesquisa em Sistemas e Arranjos Produtivos e Inovativos Locais, sediada no Instituto de Economia da Universidade Federal do Rio de Janeiro e que conta com a participação de várias universidades e institutos de pesquisa no Brasil, coordenada por José Eduardo Cassiolato e Helena Lastres. Esta rede desenvolve estudos sobre APL no Brasil e na América Latina e tem vários livros publicados sobre o tema (REDESIST, 2013). 
passaram, desde 2002, a se integrar com maior ênfase a cadeias globais de produção. Nesta perspectiva, este artigo tem por objetivo fazer uma análise da forma de inserção dos arranjos produtivos locais de carcinicultura do Nordeste, em especial do estado do Ceará, em cadeias globais de produção, e acerca de como essa inserção contribui para o dinamismo destes APLs e influencia na forma de governança local.

O artigo está dividido em quatro seções, incluída a introdução. No próximo segmento é apresentada uma breve análise da literatura sobre APL e feita uma abordagem sobre cadeias globais de produção e a forma de inserção dos APLs nestas cadeias. A terceira seção trata aspectos metodológicos da pesquisa. Na quarta, apresentam-se os resultados da pesquisa, em que se discutem os cenários mundial e brasileiro da carcinicultura, com foco nos APLs analisados, o mercado e forma de inserção das empresas em cadeias globais, assim como a forma de governança local. Por último, está a seção conclusiva.

\section{APL e cadeias globais de produção: aspectos teóricos}

De acordo com os diversos trabalhos da RedeSist, arranjos produtivos locais se referem ao conjunto de agentes econômicos, políticos e sociais, localizados em um mesmo território, com foco em um conjunto específico de atividades econômicas (tanto do setor primário, como do secundário e terciário) que pode demonstrar vínculos formais ou informais, mesmo que incipientes, no desempenho de suas atividades de produção e inovação. Constituem-se de agentes diversos (produtores de bens e serviços finais, fornecedores de insumo e equipamentos, distribuidores e comercializadoras, instituições, entre outros), e podem formar uma estrutura complexa, dependendo das suas relações e interações, propiciando economias externas fundamentais para suas competitividades. A intensidade das interações dos agentes do APL favorece o aprendi- zado e o acúmulo de conhecimentos, que podem reforçar as capacitações produtivas, técnicas e tecnológicas, interferindo no êxito e na dinâmica inovativa (BRITO e STALLIVIERI, 2010).

Por outra parte, as inter-relações interna e externa que ocorrem nos APLs trouxeram a oportunidade para que as pequenas e médias empresas, neles inseridas, integrem as cadeias globais de produção, constituído-se uma nova forma de integração ao comércio internacional (SOUZA JUNIOR et al., 2011). Tal inserção, no entanto, não é tão simples, pois a principal forma está condicionada à ação de um conjunto de agentes, os compradores que atuam no mercado (SCHMITZ e KONRRINGA, 2000). Em muitos casos, a inserção de pequenas e médias empresas de países menos desenvolvidos em cadeias globais está condicionada a exigências impostas por compradores internacionais que, na maioria das vezes, exercem a governança da cadeia.

Em decorrência desta constatação, Humphrey e Schmitz (2000) e Schmitz (2005) ressaltam a importância de incorporar a estudos de arranjo e sistema produtivos locais elementos que permitam investigar as inter-relações e suas implicações com agentes exógenos, ou seja, os vínculos externos. Para isto, sugerem a incorporação de alguns pressupostos presentes na análise sobre cadeia global de produção, realizada em Gereffi (1994, 1999) em estudos conceituais e, principalmente, empíricos.

A análise sobre a cadeia global de produção expressa em Gereffi $(1994,1999)$ e Gereffi et al. (2005) é importante instrumento para investigação da forma de organização da cadeia produtiva internacional e de como acontece a apropriação dos benefícios gerados ao longo da cadeia. Isto porque essa apropriação de valor pelos agentes sucede de maneira assimétrica. Essa cadeia é caracterizada pelos autores como de produção e comercialização de mercadorias ou produtos articulados em rede global de empresas. Assim, de acordo com Gereffi (1994, 1999), o modo de coordenação ao longo da cadeia apresenta dois formatos básicos: cadeia dirigida pelo comprador e 
dirigida pelo produtor ${ }^{4}$. A conduzida pelo comprador refere-se a segmentos industriais em que grandes detentores de canais de comercialização ou marca consolidada exercem grande influência na conformação e organização de cadeia global e, geralmente, está dispersa em vários países exportadores, localizados em economias periféricas que mantêm indústrias intensivas em mão de obra. Neste tipo de cadeia, existem agentes especializados na comercialização de produto local para mercados distintos, tais como os escritórios de exportações e as companhias de comércio, que desempenham papel fundamental na busca de vantagens competitivas dos produtores locais, pois são responsáveis pela tarefa de repassar para o mercado as capacitações acumuladas das empresas.

Para Gereffi et al. (2005), a participação das organizações dos países menos desenvolvidos em cadeias globais de mercadorias é um passo necessário para o aprimoramento produtivo, porquanto enseja importante aprendizado, fazendo com que tais empresas se tornem mais dinâmicas. Da mesma forma, estudos mais recentes, como os de Pietrobelli e Rabellotti (2011) e Navas-Aleman (2011) focam as ligações de empresas de países menos desenvolvidos em cadeias globais de valor como o caminho fundamental para o processo de aprendizado e upgrading industrial. Embora essa participação seja uma oportunidade para empresas destes países se inserirem comercialmente em cadeias globais de comercialização, no entanto, ela está condicionada à capacitação de tais empresas em proporcionar vantagens competitivas associadas a inovações tecnológicas e à redução de custos, portanto, não gerando relações com a exploração de mão de obra barata e de recursos naturais.

Suzigan et al. (2007) destacam a existência de dois tipos de cadeia dirigidos pelo comprador, de acordo com os ativos-chave que a empresa detém. No primeiro caso, as empresas coordenadoras da

4. Ver detalhes sobre a cadeia dirigida pelo produtor em Gereffi $(1994,1999)$ e Suzigan et al. (2001), pois, aqui, se trata apenas da cadeia dirigida pelo produtor, o caso dos APLs de carcinicultura. cadeia geralmente não possuem atividades produtivas e quem determina seu poder é a posse de ativos de comercialização, tais como: marca ou canais de comercialização e distribuição. Já em relação ao segundo caso, os ativos-chave são produtivos, fundamentais no desenvolvimento de produtos e da gestão de ativos comerciais.

O conceito de cadeia de produção global, entretanto, enfatiza a governança das relações ao longo da cadeia. Isto implica a coordenação das atividades econômicas mediante as relações entre mercados. Em muitos casos, os grandes compradores é que exercem forte influência sobre a dinâmica de todos os agentes envolvidos nas cadeias, inclusive a forma de organização e as estratégias dos produtores inseridos em APL.

Humphrey e Schmitz (2004) apontam que essa governança pode acontecer na forma de redes de empresas de poder mais ou menos iguais, ou na forma hierárquica ou quase hierárquica, em que uma empresa está claramente subordinada à outra, como subcontratação. Indicam, ainda, que é necessária a compreensão dos impactos das interações das instâncias locais e globais de coordenação no processo de upgrading de produtores locais, ou seja, a busca de novos nichos de produção, ou até mesmo no desempenho de atividades em outras etapas da cadeia produtiva, o que resulta em desenvolvimento de novos produtos, processos e nova forma organizacional.

Gereffi et al. (2005) mostram que a rigidez do controle exercido pelos compradores nas cadeias, as dificuldades de recursos locais para promover o upgrading e a capacidade de codificação das transações realizadas têm papel fundamental na determinação da governança das cadeias globais e de como se alteram.

Na visão de Suzigan et al. (2007), a governança em arranjos e sistemas produtivos locais é entendida como a capacidade de comando ou coordenação que determinados agentes (empresas, instituições, ou mesmo um agente coordenador) exercem sobre as inter-relações produtivas, comerciais e tecnológicas, entre outras, influenciando significativamente no desenvolvimento dos sistemas e APL, sendo a governança, por- 
tanto, um dos aspectos mais importantes dentre os que caracterizam dimensão espacial das atividades produtiva e inovativa. Ainda conforme estes autores, a existência de uma estrutura de governança, com sua forma de ação, vai depender de um complexo conjunto de fatores, cujos principais são: forma de organização da produção local (vertical e horizontal), tipo de produção ou atividade econômica local, sua base tecnológica, possibilitando ou não a divisão de trabalho e as formas como as empresas se inserem em cadeias globais.

Existem, entretanto, alguns pontos divergentes ou de crítica em relação à inserção de aglomerações produtivas em cadeias globais. Humphrey e Schmitz (2000), por exemplo, argumentam que essa abordagem exprime uma análise limitada do papel dos agentes locais na estrutura de coordenação e estratégia de capacitação das aglomerações produtivas, ressaltando, portanto, que as formas de cooperação ao longo da cadeia global de produtores subestimam o papel das práticas locais de cooperação e regulação governamental no âmbito nacional ou internacional.

Com efeito, Cassiolato e Szapiro (2003) ressaltam que as análises disponíveis sobre os países centrais, embora tenham incorporado elementos disponíveis sobre a coordenação das atividades ao longo da cadeia, retratam visão reducionista, por considerarem que a única possibilidade das aglomerações produtivas locais de micro e pequenas empresas, em países menos desenvolvidos, se transformarem em sistema locais dinâmicos é por conta da participação em cadeias coordenadas por agentes externos em tais países. Vários estudos de arranjos produtivos locais em diversos países, inclusive no Brasil, demonstram a existência de arranjos que demonstram certo dinamismo, independentemente de participarem de cadeias produtivas globais, ou seja, se sobressaem, mesmo participando em mercados locais regionais e nacionais.

Por outro lado, Schmitz (2005) também ressalta que a inserção em cadeias globais, embora facilite a capacitação de produtores locais, em termos de produção, o mesmo não se pode afir- mar quanto à capacitação que vai além da produção. Isto significa que a inserção pode expressar estrangulamento dos produtores locais, na medida em que encontram dificuldades em acessar etapas da cadeia produtiva que incorporem maior valor agregado. $\mathrm{Na}$ agroindústria, por exemplo, as principais atividades geradoras de valor agregado não se encontram na produção, mas em outros ativos, como a concepção e o desenvolvimento de formas mais sofisticadas de processamentos, embalagens, padrão mínimo de qualidade, posse de canais de comercialização e distribuição de produto, entre outras atividades. Se a posse destes ativos estiver em mãos de agentes exportadores, os arranjos produtivos terão dificuldades para se apropriar dos benefícios e vantagens competitivas geradas, ficando o valor originado ao longo da cadeia produtiva para os agentes de comercialização. Este fato está sendo expresso com muita ênfase para as empresas brasileiras, porquanto os agentes de comercialização é que estão se apropriando destes ativos essenciais. Estudos mais recentes, como os de Suzigan et al. (2007), Bracarense e Botelho (2009) e Souza Junior et al. (2011) constataram que, embora determinadas aglomerações produtivas apresentem certo dinamismo baseado na interação dos agentes, muitas delas são incapazes de se apropriar do valor gerado localmente por conta de sua posição na cadeia global.

À luz dessa abordagem conceitual, a seguir, se fará análise de como procede a forma da inserção da carcinicultura do Nordeste, em particular, dos APLs do estado do Ceará em cadeias globais de produção, visto que as empresas estiveram potencialmente voltadas para o mercado externo.

\section{3. Área de estudo e procedimento metodológico}

O estudo teve por base os APLs de cultivo de camarão localizados no Ceará, onde tal atividade se desenvolve desde 1982 e, em 2011, contou 325 produtores, dos quais $52,3 \%$ são micro $(<3$ hectares), $15,1 \%$, pequenos (3-10 hectares), $23,4 \%$, 
médios (10-30 hectares) e 9,2\%, grandes produtores (>30 hectares) (ABCC, 2013a). Cabe informar que os empreendimentos de carcinicultura, na sua maioria, se localizam na faixa litorânea, principalmente nos mananciais com influência das águas salinas. Ao longo dessa faixa litorânea, encontram-se dois arranjos produtivos locais de cultivo de camarão bem característicos, representando 270 do total de produtores do estado, tais como:

1. Arranjo Produtivo de Cultivo de Camarão do Litoral Oeste - situado na microrregião Acaraú/Camocim, ao noroeste do estado do Ceará. Nesse arranjo, estão em funcionamento 94 empresas, em sua maioria, de pequeno e médio porte. Dentre as grandes empresas em operação, correspondentes a 11 no total, quatro são verticalizadas, pois atuam desde a larvicultura até o processamento do produto final.

2. Arranjo Produtivo de Cultivo de Camarão do Litoral Leste - localizado na microrregião Litoral Aracati e Baixo Jaguaribe, no leste do Ceará. Esse APL é composto por 176 empresas, na maioria, micro e pequenas, em geral de base familiar ou comunitária, especialmente as microempresas (Figura 1).
Ambos os APLs possuem estrutura produtiva complexa, contando com a presença de vários segmentos ligados à cadeia produtiva da carcinicultura, envolvendo alguns correlatos e de apoio, como fornecedores de ração, pós-larvas e outros equipamentos (utensílios e outros artefatos), além da presença de instituições de ensino.

Foi realizada uma pesquisa descritiva para determinar a forma de integração dos APLs de cultivo de camarão do Ceará a cadeias globais, através de delineamento de estudo de caso, considerando, particularmente, a descrição e a compreensão dos fenômenos sociais complexos, por meio das relações de fatores em um contexto social selecionado. As informações foram obtidas por levantamento de dados primários e secundários. Com relação aos dados primários, as principais técnicas de coleta empregadas foram entrevistas semiestruturadas, realizadas durante as visitas aos produtores (proprietários das fazendas de camarão), gerentes executivos de processadoras/distribuidoras e escritórios de exportações localizados no Ceará. Foram entrevistadas 35 empresas, sendo 20 no APL do litoral Leste e 15 no APL do litoral Oeste do estado, assegurando a representatividade das micros, pequenas, médias e grandes empresas (fazendas de cultivo) que possuíam plantas de processamento,

Figura 1. Localização dos APLs de cultivo de camarão no Ceará

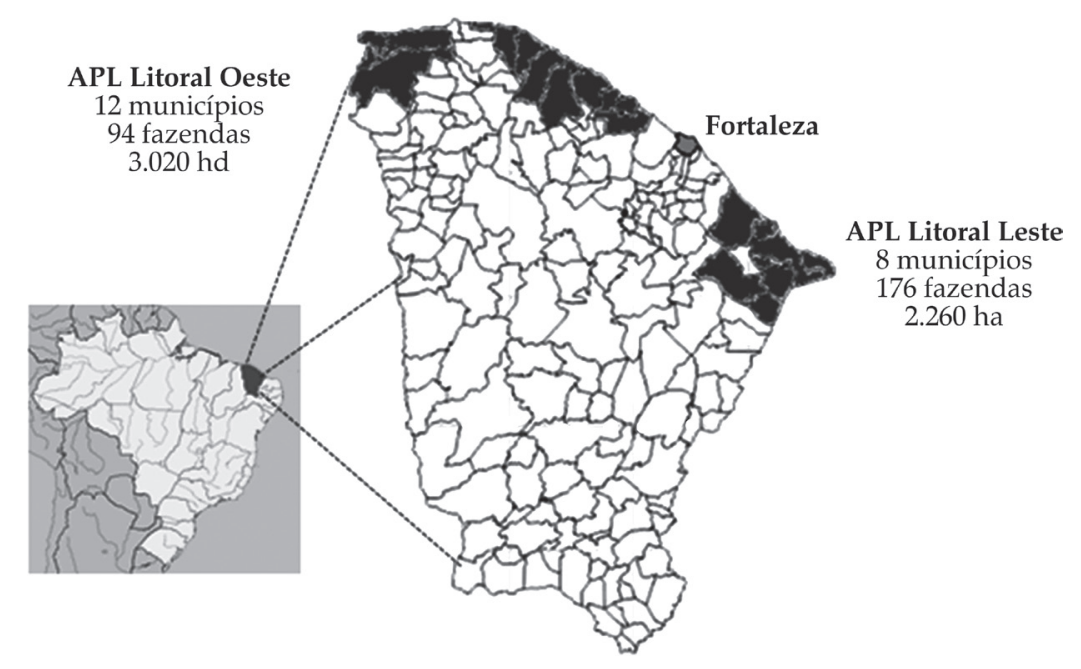

Fonte: Elaboração própria. 
além de escritórios de exportação como forma de captar, baseado em visão sistêmica, as características e comportamentos de toda a cadeia produtiva, considerando alguns aspectos como: forma de inserção dos produtores no mercado externo e interno; o papel dos compradores na coordenação do sistema de produção local, a forma de interação entre os produtores locais e agentes externos (comparadores), bem como a forma de coordenação ou comando local (governança).

Os dados secundários vieram de fontes oficiais como: estatísticas da Associação Brasileira de Criadores de Camarão (ABCC), o censo da carcinicultura nacional em 2011 da ABCC, levantamentos da FAO (Food and Agriculture Organization of United Nations), da Secex/MDIC (Secretaria de Comércio Exterior do Ministério do Desenvolvimento, Indústria e Comércio Exterior), da NMFS (National Marine Fisheries Service), da Globefish, que conferem uma visão geral do segmento que vai desde produção, exportação, número de produtores etc.

\section{Resultados e discussões}

\subsection{O panorama mundial e brasileiro da carcinicultura}

A carcinicultura é uma atividade aquícola que tem se expandido nas últimas décadas, particularmente em países menos desenvolvidos de costas tropicais da Ásia e América Latina, que respondem por $99,7 \%$ da produção, na sua maioria direcionada para o mercado internacional dentro de um contexto de estratégia de desenvolvimento e crescimento orientado para exportação de muitos países menos desenvolvidos (FAO, 2012). Essa expansão está associada a fatores como o crescente mercado internacional para o produto, o nível de rentabilidade e, principalmente, a geração de divisas para as regiões ou países produtores.

Os países asiáticos são os maiores produtores de camarão cultivado, uma vez que, do total de 3,9 milhões de toneladas produzidas em
2011, 85,9\% são originários destes. A China é a líder global, respondendo por 39,6\% da produção mundial, seguida da Tailândia $(13,8 \%)$ Vietnã $(12,6 \%)$ e Indonésia (10,2\%). Na América, a produção está concentrada nos países do Centro-Sul, respondendo por 13,3\% da produção total, destacando-se como maiores produtores Equador (266 mil toneladas), seguido pelo México (109,9 mil t) e Brasil (69,4 mil t). Os dez maiores produtores mundiais concentram $92,3 \%$ do total. O Brasil é o nono maior produtor mundial, com apenas 1,8\% (FAO, 2013).

De acordo com Rocha (2006), a carcinicultura, tanto nos países asiáticos como da América, é caracterizada pela presença maciça de micros, pequenos e médios produtores, concentrados em áreas específicas. Na Ásia, por exemplo, a China conta com 300.000 micros e pequenos produtores, o Vietnã com 160.000, a Indonésia com 150.000 e a Índia com 120.000 , sendo que 82.000 deles exploram áreas inferiores a dois hectares. Observa-se, ainda, que a forma de organização e estrutura produtiva dos países asiáticos aponta para a existência de aglomerações produtivas, com um diferencial em relação à America Latina, em particular, ao Brasil, pois na Ásia estas aglomerações contam com o apoio dos seus governos e de vários setores envolvidos na produção, processamento e distribuição. Também são mais inovadores no desenvolvimento de novas formas de beneficiamento do produto, razão pela qual conseguem obter espaço importante no mercado internacional.

No Brasil, a carcinicultura foi impulsionada em 1998, primeiramente, com introdução da espécie $P$. vannamei, quando a produção saltou de 7.250 no referido ano para 90.190 t em 2003, com taxa média de crescimento de $67 \%$ ao ano. Após este período, contudo, a produção de camarão cultivado se estabilizou na média de 69.892 t/ano nos últimos quatros anos (Figura 2). Esta expansão, segundo Madri (2006), foi beneficiada pela política econômica e pelas condições favoráveis no mercado mundial, embora estes fatores tenham se modificado ao longo dos últimos anos, tornando a situação altamente instável. Outro 
Figura 2. Evolução da produção/produtividade/área cultivada da carcinicultura brasileira - 1998 a 2011

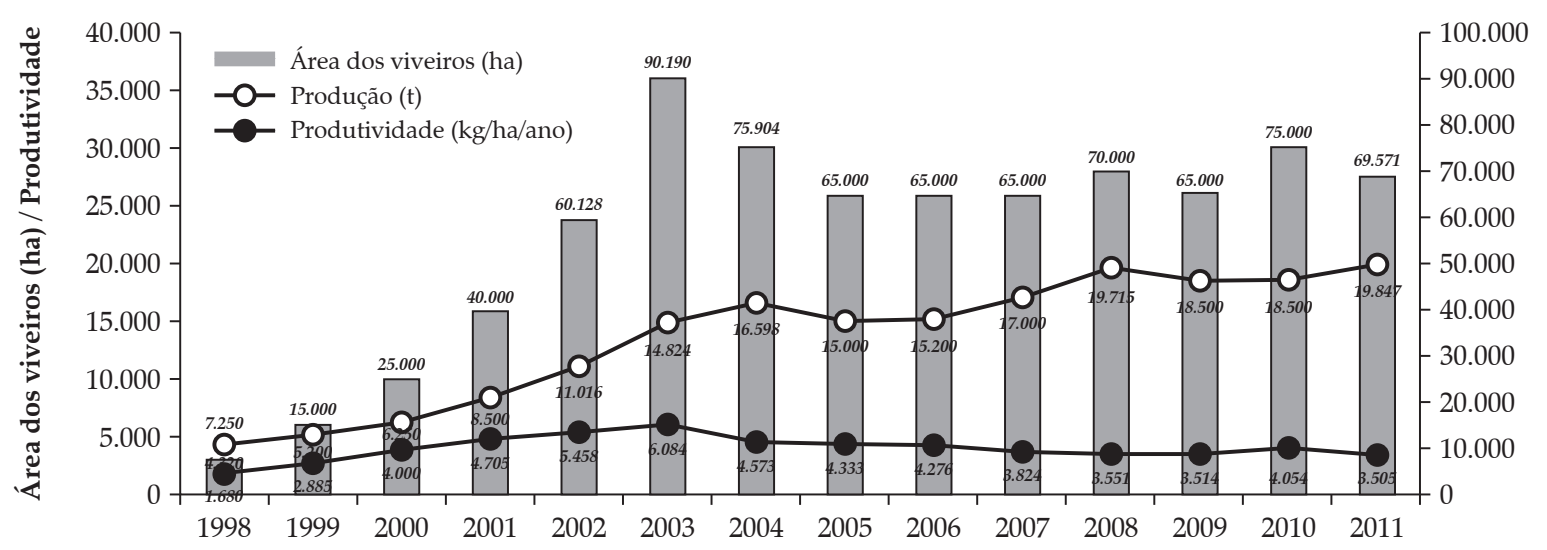

Fonte: ABCC (2013a, 2013b).

fator relevante é a taxa de produtividade considerada uma das maiores do mundo, com média de $3.505 \mathrm{~kg} / \mathrm{ha} / \mathrm{ano}$, estando, portanto, acima da média mundial que, é de $931 \mathrm{~kg} / \mathrm{ha} / \mathrm{ano}(\mathrm{ABCC}$, 2013a).

A região Nordeste detém a maior concentração de produção de camarão marinho do Brasil, formando, nesta região, arranjos produtivos locais como estratégia de organização da produção. Ela responde por 99,3\% da produção nacional e por 92\% do total de produtores, com destaque para o Rio Grande do Norte e Ceará, que concentram o maior número de empreendimentos, com 360 e 325, respectivamente. Estes estados produziram, na mesma ordem, 17,7 mil e 31,9 mil toneladas em 2011, correspondendo a 71,5\% da produção total (ABCC, 2013a), e foi identificada a presença de arranjos produtivos locais bem característicos, cujas estruturas produtivas mostram assimetrias, tanto no que refere a distintos tamanhos das empresas quanto ao variado poder de mercado. Uma vez que a atividade é marcada pela predominância de micros, pequenos e médios produtores, os quais somados representam $65,3 \%$ e $86,4 \%$ do total de empreendimentos, respectivamente para os estados do Ceará e Rio Grande do Norte, e ainda verifica-se a existência de grandes empresas verticalizadas com maior poder de mercado, sendo esta uma atividade que proporciona divisas, emprego (SILVA e SAMPAIO, 2009; ABCC, 2012).

\subsection{Mercado mundial para o camarão}

Para a compreensão da dinâmica da indústria de camarão é necessário entender como operam o mercado e as aglomerações produtivas do segmento e, em particular, as relações entre os países menos desenvolvidos e os mercados daqueles mais desenvolvidos.

A demanda do mercado mundial do camarão era praticamente atendida pela produção vinda de captura. Somente com o início da década de 1990, ocorreu o incremento da oferta global desse produto em decorrência da intensificação do cultivo de camarão em cativeiro em diversos países asiáticos e latino-americanos. Os maiores produtores responderam por $62,6 \%$ do volume e por $65,7 \%$ do valor total das exportações mundiais em 2011, destacando-se como maiores exportadores asiáticos a Tailândia, a China e o Vietnã, e na América Latina, Equador e México (GLOBEFISH, 2012). Esses países respondem pelo incremento da produção de camarão cultivado e consequente expansão do mercado global do produto.

Os maiores mercados consumidores são os Estados Unidos, Europa e Japão. O mercado europeu ocupa a primeira posição, com 49,9\% das importações; em segundo ugar, está o mercado norte-americano, com $33,4 \%$, seguido pelo Japão, com $16,7 \%$ do total. A demanda por camarão cresceu bastante, não só entre os países centrais, 
como também em países emergentes, especialmente no sudoeste asiático e Extremo Oriente, onde o consumo aumentou consideravelmente. Japão e China são os maiores mercados da Ásia mas, enquanto_o japonês, nos últimos anos, tenha praticamente se estagnado, a China apresentou incremento no consumo de camarão, aumentando também sua participação nas importações do produto. Já o mercado europeu, levando-se em conta a média do crescimento das importações dos seus principais países, cresceu mais do que o dos Estados Unidos. Apesar da crise econômica que se instalou na zona do euro a partir de 2012, as exportações de camarão para os países da União Europeia continuaram crescendo, atingindo $551.643 \mathrm{t}$ em 2011, tendo como grandes importadores a Espanha (20,4\%), França (13,7\%), Dinamarca $(12,4 \%)$, Reino Unido (10,3\%), Itália $(8,8 \%)$ e Alemanha $(7,4 \%)$ (GLOBEFISH, 2012).

Os países asiáticos são os maiores exportadores para os Estados Unidos e para o Japão. A Tailândia e a Indonésia destacam-se como grandes fornecedores para o EUA, com destaque também para o Equador, como terceiro exportador para esse mercado. No caso do Japão, os principais fornecedores são os países do seu entorno Vietnã e Tailândia, seguidos por Indonésia e Índia. Os grandes fornecedores para Europa são os países da América do Norte/Sul - Equador, México e Argentina e, mais recentemente, os países asiáticos, como Tailândia e Índia. O Brasil perdeu mercado para estes países por diversos fatores, o que será discutido na seção seguinte.

O mercado para a indústria de camarão é altamente segmentado. Este fracionamento do mercado ocorre tanto pela diferenciação do produto quanto de preço. As diferenciações ocorrem em razão do tamanho do camarão (peso), do seu congelamento inteiro, sem cabeça e/ou sem casca, pré-cozido ou cru, enlatado, empanado e outras formas, do tipo "pronto para consumir". Os países desenvolvidos são os maiores demandantes de produtos com maior valor agregado. No caso dos Estados Unidos, por exemplo, observa-se uma preferência pelo camarão sem casca congelado para empanar e outras formas de preparo. $\mathrm{O}$
Japão é pioneiro em importar camarão cru, para processar na forma de Nobashi \& Sushi (sem casca/ sem vísceras/retos/com cauda além de camarão cozido congelado. Entanto, os países europeus se caracterizam pela importação do produto congelado inteiro, para reprocessamento e camarão preparado em conserva, incluindo o cozido (GLOBEFISH, 2012; FILOSE, 2009). Essa segmentação faz com que a concorrência entre os países produtores não ocorra em torno de um mercado geral, mas sim em seus diversos segmentos específicos. Efetivamente, a diferenciação de produto, além de reforçar as barreiras à entrada em nichos de mercado mais especializados, é também necessária para complementar ou substituir as competições via preço. De acordo com o tipo de agregação de valor ao produto, verificam-se diferenças significativas nos processos de produção e beneficiamento, fazendo com que as empresas nos diversos países produtores apresentem estruturas produtivas e de beneficiamento distintas e com dinâmica própria e até mesmo capacitações diferenciadas. Estes fatores, conforme apontam Garcia et al. (2004), podem reduzir a possibilidade de aproveitamento de economia de escopo.

\subsection{Inserção das empresas de cultivo de camarão do Nordeste - APLs do Ceará - no mercado internacional}

A inserção das empresas de camarão cultivado do Nordeste no mercado internacional ocorreu em 1998, quando a produção se voltou para o mercado estadunidense, onde havia crescente demanda por camarão, levando-o a buscar preços mais baixos, o que foi encontrado no Nordeste do Brasil. Este fato ocorreu praticamente com a produção das empresas concentradas em APLs do litoral Leste e Oeste do estado do Ceará. Os APLs deste estado foram responsáveis por cerca de $86,6 \%$ do valor total das exportações brasileiras de camarão cultivado (ABCC, 2013b). O acesso dos APLs do Ceará no mercado externo ocorreu pela intermediação de agentes de exportação e grandes empresas internacionais que detêm o controle dos canais de comerciali- 
zação e distribuição. Esta inserção representou um grande salto nas trajetórias de desenvolvimento destes APLs, mesmo que ela, em grande parte, tenha ocorrido via integração das empresas de tais arranjos em cadeias globais que, conforme ressaltado, controlam estádios estratégicos do processo de agregação de valor ao produto, nas quais os produtores locais têm participação bastante reduzida. Cassiolato e Szapiro (2003) afirmam que participação dos APLs em cadeias globais de produção influencia intensamente as suas capacitações produtiva e inovativa, bem como a organização desses arranjos, conforme será discutido na sequência.

A partir de 1999, não só os Estados Unidos passaram a importar camarão cultivado brasileiro, como também a Europa, levando à reestruturação da maioria das empresas de processamento que antes só beneficiavam pargo e lagosta para exportação. Além disto, foram construídas pelos grandes compradores estruturas de comercialização para o camarão brasileiro, em especial com o estabelecimento de escritórios de exportação. Essa reestruturação causada pelo impulso das exportações foi capaz de conferir às empresas dos APLs de camarão cultivado no Nordeste brasileiro certo dinamismo, que pode ser verificado pela rápida expansão da produção e das exportações. Essa expansão permitiu que empre- sas brasileiras, entre 2003 a 2005, chegassem a ocupar a sétima posição no mercado internacional e de terceiro maior exportador da América Latina, perdendo apenas para Equador e México, neste mesmo período. Em 2003, por exemplo, as empresas concentradas no Nordeste tornaram-se as principais exportadoras de camarão de médio e pequeno porte para os EUA, com 17.463 t/ano. No ano seguinte, houve um redirecionamento das exportações para a Europa (Espanha, França, Portugal, entre outros), ocupando o primeiro lugar na pauta de importação desse continente, com 43.019 t/ano. Ante o expressivo crescimento das exportações, no início da década de 2000, foi consolidada a posição dos produtores de camarão do Nordeste brasileiro, em especial, dos produtores dos APLs do Ceará, no mercado internacional. Cabe destacar o papel fundamental dos agentes exportadores nesse processo, porquanto não houve grandes investimentos no estabelecimento de canais próprios de comercialização para a conquista de mercado internacional.

O desempenho exportador das empresas de camarão pode ser visto na Figura 3, atingindo o auge em 2003 com 58,4 mil t, no valor de US\$ 225,9 milhões (FOB), caindo, em seguida, significativamente, até atingir $108 \mathrm{t}$, no valor de US\$ 0,9 milhões (FOB) em 2011. Vários fatores contribuíram para esse decréscimo, destacando-se como

Figura 3. Evolução da produção e exportação (t/valor) brasileira de camarão cultivado, no período de 1998 a 2011

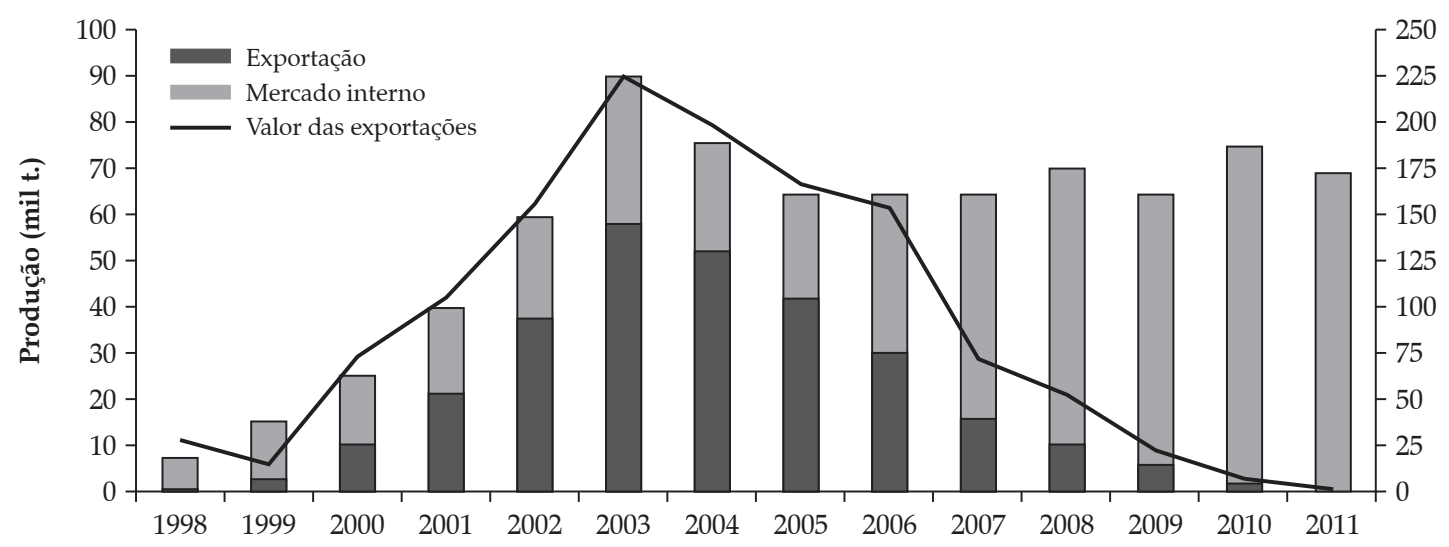

Fonte: Secex/MDIC (2013) e ABCC (2013b). 
principais a valorização do real; a queda nos preços no mercado internacional; a perda de competitividade para países como China, Tailândia e Indonésia - que oferecem camarão a preços menores, em decorrência dos baixos custos de mão de obra, e por ofertarem também produtos com maior valor agregado - além dos efeitos da ação antidumping promovida pelos Estados Unidos contra vários países produtores/exportadores de camarão, inclusive o Brasil. Rocha (2011) e Madri e Wurmann (2011) argumentam, ainda, que, além destes fatores, a perda de competitividade da carcinicultura brasileira está também associada à falta de políticas públicas que possam levar a maior eficiência em toda a cadeia produtiva a médio e longo prazo.

Apesar de a inserção no mercado externo ter se iniciado pelas empresas dos APLs do Ceará, aquelas concentradas no Rio Grande do Norte lideram as exportações atualmente, com $66,7 \%$ do total exportado. $\mathrm{O}$ destino das exportações continua sendo a Europa (França e Espanha). Os dois estados foram responsáveis, em média, por $79,6 \%$ das exportações de camarão cultivado brasileiro, embora estas tenham caído drasticamente a partir de 2005 (Tabela 1). São apenas esses estados que ainda continuam inseridos no mercado externo. A perda de competitividade neste mercado fez com que os produtores passassem por grandes dificuldades por não possuírem canais de comercialização e distribuição consolidados no mercado interno. Neste quadro, muitas empresas de pequeno e médio porte dos APLs do estado do Ceará não conseguiram sobreviver ao cenário extremamente desfavorável do mercado externo, visto que, às vezes, os preços para determinadas classificações caíam abaixo do custo de produção. Nesse período, muitas empresas foram desativadas, de modo que, somente em 2010, com o ajuste do sistema de produção e investimento no processo de comercialização, incluindo promoção e divulgação, permitiu o início da recuperação e/ ou consolidação do mercado interno, voltando, então, essas empresas a produzir. Com isto, a participação no mercado doméstico passou de 31\% em 2004 para 99\% em 2011.

Cabe ressaltar, no entanto, o fato de que as indústrias de beneficiamento de camarão nos APLs estudados fazem somente a classificação por tamanho e congelamento em blocos e, em menor escala, a retirada da cabeça e, às vezes, filetagem, não havendo, portanto, diferencial de produtos por agregação de valor, o que caracteriza o Brasil como um mero exportador de matéria-prima para processamento adicional nos países importadores. A Espanha, por exemplo, costuma comprar o camarão brasileiro in natura de pequeno e médio porte para reprocessamento, pondo a marca de suas empresas, e distribui para outros países da Europa. Nota-se que o desempenho exportador das empresas de camarão dos APLs do estado do Ceará dependia totalmente das condições desses mercados.

Visto que as empresas de cultivo dos APLs do Ceará exportam apenas matéria-prima, o valor médio adquirido pelas exportações de camarão fica abaixo de outros países produtores, uma vez que o preço médio pago é mais baixo, por não

Tabela 1. Volume das exportações de camarão cultivado dos estados do Rio Grande do Norte e Ceará - 2001 a 2011

\begin{tabular}{|c|c|c|c|c|c|c|c|c|c|c|c|}
\hline \multirow{2}{*}{ Estados } & \multicolumn{11}{|c|}{ Volume (t)/Ano } \\
\hline & 2001 & 2002 & 2003 & 2004 & 2005 & 2006 & 2007 & 2008 & 2009 & 2010 & 2011 \\
\hline $\mathrm{RN}$ & 5.584 & 11.377 & 18.760 & 21.165 & 15.962 & 10.889 & 8.208 & 6.195 & 4.586 & 1.585 & 72 \\
\hline $\mathrm{CE}$ & 6.324 & 13.585 & 20.126 & 16.541 & 15.167 & 12.825 & 4.633 & 1.908 & 726 & 6 & 36 \\
\hline Subtotal & 11.908 & 24.962 & 38.886 & 37.706 & 31.129 & 23.714 & 12.841 & 8.103 & 5.312 & 1.591 & 108 \\
\hline Brasil & 23.408 & 39.643 & 60.724 & 54.379 & 45.033 & 33.918 & 17.197 & 10.931 & 6.421 & 2.282 & 108 \\
\hline \multicolumn{12}{|c|}{ Participação do Ceará e do Rio Grande do Norte (em \%) } \\
\hline $\mathrm{RN}$ & 26,3 & 30,1 & 32,1 & 40,6 & 38,1 & 36,2 & 52,9 & 65,9 & 80,1 & 99,0 & 66,7 \\
\hline CE & 29,8 & 35,9 & 34,4 & 31,7 & 36,2 & 42,6 & 29,9 & 20,3 & 12,7 & 0,4 & 33,3 \\
\hline
\end{tabular}

Fonte: Secex/MDIC (2013) e ABCC (2013b). 
haver incorporação de atributos diferenciados ao produto.

Verifica-se, contudo, que os produtores de camarão dos países menos desenvolvidos, que exportam grande parte de sua produção, enfrentam um padrão de concorrência na indústria de camarão, de modo geral, ainda baseada em preço, custo baixo de mão de obra e pouca ou quase nenhuma preocupação relativa à questão ambiental, sobretudo nos países asiáticos (Vietnã, China, Indonésia, Tailândia e Índia) e em países como Brasil, Equador e México, na América. Esse tipo de concorrência é classificada como espúria, pois ainda é baseada em fatores tradicionais de competitividade, como preço, baixo custo de mão de obra, exploração de recursos naturais e variação cambial.

Essa realidade está mudando, pois se observa que algumas empresas produtoras de camarão em determinados países, como o Brasil, em particular em algumas empresas dos APLs do Ceará, estão atentas às exigências do mercado externo, principalmente o europeu. Deste modo, estão implantando normas de qualidade, biossegurança, certificação e selos ambientais, selo de produção orgânica, entre outros, buscando, assim, outras formas de competitividade mais dinâmicas e sustentáveis, sobretudo, em novas tecnologias de manejo e agregação de valor ao produto. Isto porque os consumidores, em especial o europeu e os norte-americanos, estão cada vez mais exigentes quanto à segurança alimentar (como a inocuidade) e questões ambientais. Para Filose (2009), atributos como preço, sabor, valor nutricional e qualidade, entre outros, se tornam insignificantes se existir dúvida acerca da segurança alimentar, considerada primordial para tais consumidores. Os grandes compradores passarão a exigir, em pouco tempo, que as empresas tenham um sistema da rastreabilidade e produção de forma sustentável.

A estratégia de inserção foi modificada, em 2009, quando o mercado interno passou a ser o destino de $99 \%$ do camarão produzido no APL do litoral Leste e 97\% do litoral Oeste do Ceará. A maior parte do camarão vendido no Brasil vai para os mercados do Rio de Janeiro, São Paulo e Brasília (76\%). O restante (24\%) é distribuído no Ceará. Somente $1 \%$ e 3\% do camarão produzido, respectivamente, no APL do litoral Leste e do litoral Oeste do estado foram destinados a exportações. Neste caso, são empresas distribuidoras internacionais que detêm o controle da cadeia, se sobrepondo aos interesses das empresas locais. Assim, os grandes compradores de camarão brasileiro optaram por substituí-los por outros fornecedores, fazendo com que as empresas produtoras de camarão ficassem vulneráveis no que concerne à comercialização de sua produção. Isto porque os canais de comercialização e distribuição para o mercado externo são de propriedade dos grandes compradores. Dessa forma, os produtores destes APLs ficam dependentes dos compradores externos. Para mudar essa realidade, as empresas produtoras têm que se adequar às novas formas de produção, comercialização e distribuição, estando sintonizadas com as exigências do mercado consumidor, em especial o externo, quanto às questões ambientais e de sanidade, garantindo, assim, maior competitividade (SILVA e MARTINS, 2012). Esses fatos levam à análise da forma de confirmação da cadeia produtiva da indústria de camarão brasileira e sua integração com a cadeia internacional.

\subsection{Configuração da cadeia produtiva da indústria do camarão}

A configuração da cadeia internacional da indústria do camarão não se diferencia muito de outros segmentos industriais, sendo que o seu principal agente são as grandes empresas compradoras internacionais - importadoras que mantêm relação com os produtores/processadores por meio de agentes especializados na compra de produtos específicos de camarão para o mercado internacional, caracterizando-se, portanto, com uma cadeia dirigida pelo comprador, conforme a classificação de Gereffi (1994). Estas empresas é que determinam o preço do camarão, detendo o maior poder de barganha junto aos produtores, impondo, inclusive, seus interesses, por possuí- 
rem ativos essenciais relacionados aos comandos dos canais de comercialização e distribuição. Retêm, ainda, ativos intangíveis fundamentais, como acesso a vários mercados, marcas consolidadas no mercado onde atuam, capacidade para desenvolver novos produtos à base de camarão para atender a demanda dos consumidores que buscam cada vez mais produtos "prontos para o consumo".

As grandes empresas compradoras de camarão, geralmente, mantêm escritórios nos países produtores, os quais têm a função de representá-las junto aos produtores/processadores, e são responsáveis pela compra e distribuição do produto para seus respectivos demandantes. Por meio desses escritórios, as empresas podem adquirir os seus produtos em qualquer país produtor de seu interesse, desde que este atenda aos seus requisitos, como preço, qualidade sanitária e ambiental, sabor, valor nutricional e até capacidade de beneficiamento do camarão. Isto mostra que os produtores/processadores exercem pouca influência na conformação da cadeia internacional, pois os grandes compradores é que controlam as formas de governança desta cadeia. De acordo com entrevistas realizadas nas empresas de processamento dos APLs no Ceará, as importadoras chegam às vezes a indicar inspetores para verificar o controle de qualidade na produção e no semiprocessamento do camarão, para garantir que este chegue ao destino final atendendo a todos os requisitos. De certa forma, este fato contribui para o processo de aprendizado e geração de inovações, mesmo que incrementais e, consequentemente, melhorias no processo de produção e qualidade do produto.

No que tange à conformação da cadeia produtiva internacional da indústria de camarão, os maiores mercados importadores mostram canais de comercialização e distribuição bastante semelhantes. As empresas compradoras adquirem grandes quantidades de camarão de vários tamanhos e formas de preparo. Dependendo do tipo de produto, se for o caso, reprocessam e distribuem para as redes de serviços alimentícios. Essas aquisições são intermediadas pelos agentes de exportação, que geralmente especificam o tipo de classificação e preparo, e até o preço. A maior parte das empresas importadoras é verticalmente integrada, especialmente as da Europa, ou seja, além de compradoras, são também processadoras e distribuidoras.

A forma organizacional da cadeia produtiva internacional com a participação das empresas do Nordeste - APLs do Ceará - é mostrada na Figura 4. Conforme pode ser visto, os principais compradores dessas empresas são as grandes organizações integradas da Europa, em particular as da França e Espanha, e determinam a forma de preparo da matéria-prima. Deste modo, os produtores/processadores ficam sujeitos a todos os tipos de exigências impostas por estas compradoras, inclusive, as margens de rentabilidade dos produtores, visto que os preços são fixados por eles. Além disto, o número de empresas compradoras é bastante reduzido e concentrado nos grandes mercados consumidores, elevando ainda mais o poder de barganha destas junto aos produtores. Deste modo, o acesso das empresas dos APLs de cultivo de camarão do Ceará ao mercado externo ocorreu via agentes de intermediação e das grandes redes de compra e distribuição internacional. Estas organizações internacionais é que detêm a posse dos canais de comercialização e determinam o preço do produto, ficando as empresas dos APLs na dependência destas grandes redes para a venda de camarão no mercado externo.

Além dos principais agentes que configuram essa cadeia, como laboratório de larvicultura, fazendas de engorda e centros de processamento, entre outros, destaca-se o papel desempenhado pelos técnicos locais de avaliação e compra do camarão, representantes das empresas processadoras/exportadoras. Eles são responsáveis pela compra de camarão junto aos produtores locais e têm a função de verificar, antes da compra, se o camarão está dentro dos padrões de qualidade exigidos por compradores internacionais. Esses agentes têm papel fundamental no aprendizado, por atuarem mais próximos aos produtores e interagirem com maior frequência, possibilitando 
Figura 4. Forma organizacional da cadeia produtiva internacional da indústria de camarão e a participação das empresas do estado do Ceará (APL de cultivo de camarão do Ceará)

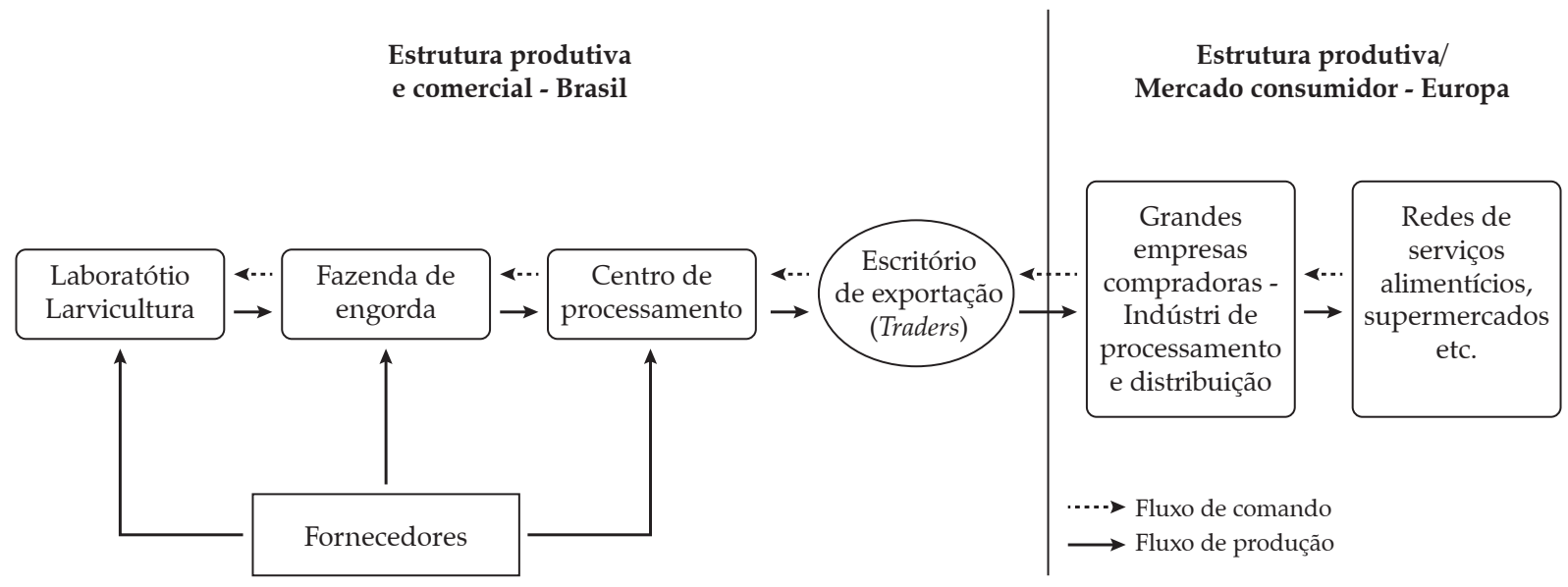

Fonte: Elaboração própria, com base em Gereffi (1994).

a troca de informações. Essas informações transmitidas pelos agentes de compra (geralmente técnicos especializados em carcinicultura) aos produtores restringem-se aos elementos tecnoprodutivos relacionados ao processo de produção. Schmitz e Knorringa (2000) ressaltam que os agentes atuantes na comercialização podem fomentar processos de aprendizagem muito importantes, especialmente na esfera produtiva, já que eles possuem estruturas de prestação de serviços aos produtores nos vários locais.

Assim como em outros segmentos, as principais vantagens competitivas das empresas de camarão estão diretamente associadas à melhoria da capacidade produtiva e inovativa, significando o desenvolvimento de produtos à base de camarão, de melhores processos no controle das condições sanitárias e ambientais, e ainda da capacidade da gestão da sua cadeia produtiva. Neste caso, os produtores de camarão do Nordeste têm como ativos essenciais a produção de commodities, o que restringe sua participação na cadeia produtiva, deixando os produtores bastante vulneráveis e pouco competitivos. Esta vulnerabilidade foi bastante acentuada com a queda brusca das exportações, a partir de 2007, pois praticamente inexistiam estratégias das empresas produtoras e processadoras de camarão voltadas para o mercado interno. De fato, não se verificava, nesse período, um esquema de comercialização e distribuição consolidado, à semelhança daquele observado para o mercado externo.

Cabe ressaltar, no entanto, que algumas empresas produtoras de camarão implantaram nas grandes cidades brasileiras uma rede de restaurantes do tipo "comida rápida" à base de camarão, tais como "Vivenda do Camarão", "Camarão $\mathcal{E}$ Cia" e "Camarão Box", como estratégia para incentivar o consumo no mercado interno e a venda direta ao consumidor.

Em entrevista com os gestores/proprietários das processadoras/exportadoras nos APLs do Ceará, por exemplo, eles ressaltaram que não compensava, na época, vender o camarão para o mercado interno por conta dos impostos, preferindo o mercado externo por serem isentos do ICMS (imposto de circulação de mercadoria e serviços), mesmo com a obtenção de uma margem de rentabilidade muito baixa. Outro fato apontado pelos produtores era o de que as vendas para o mercado doméstico eram em reduzida quantidade e muito pulverizadas, não existindo compradores certos, necessitando de um apoio logístico maior. Além da alegação, por parte dos produtores entrevistados, da falta de confiança nos agentes de comercialização, se sobressaía 
também a frágil estrutura da organização dos canais de comercialização do mercado interno. Evidentemente, a ausência de confiança entre produtores e comerciantes atrapalhava o processo de aprendizagem local e retardava o desenvolvimento tecnológico dos arranjos produtivos locais, pois, de acordo com Schmitz e Nadvi (1999), as aglomerações produtivas só se tornarão dinâmicas e inovativas se houver relações comerciais consolidadas, em que a confiança sustenta as relações entre as empresas.

Outro fator que contribuiu para a reduzida participação do mercado interno no faturamento das empresas produtoras de camarão foi a baixa demanda do produto no Brasil, devido à incipiente taxa de consumo de camarão, que em 2004 era de 0,25 kg per capita, diferente da China, Tailândia e Malásia, que apresentam um mercado interno bastante desenvolvido em decorrência da demanda crescente por camarão. Entretanto, o crescimento do poder aquisitivo da população, favorecendo o aumento da taxa de consumo para 0,54 kg per capita, em 2010 e, também a queda do ICMS, em 2008, foram importantes para impulsionar a produção para o mercado interno, favorecendo os produtores que passaram a estabelecer e consolidar novos canais de comercialização para atender a crescente demanda pelo produto (ROCHA, 2011).

Apesar da organização e consolidação dos canais de comercialização e distribuição para o mercado interno, os produtores ainda têm problemas com relação à infraestrutura e logística. A distribuição da produção, nos últimos anos, em ambos os APLs analisados, sucede da seguinte forma: os agentes de comercialização, externos ao arranjo, compram diretamente do produtor o camarão in natura e resfriado; em seguida, distribuem para os estabelecimentos comerciais (centrais - Ceasa/Ceagesp, peixarias, feiras e supermercados). Somente em cerca de $15 \%$ o camarão produzido é semiprocessamento (retirada da cabeça e/ou casca) nas empresas processadoras locais que repassam para os estabelecimentos comerciais - sistema de serviços alimentícios, redes de supermercados etc.
A qualidade do camarão vendido no mercado doméstico, porém, ainda deixa muito a desejar, por apresentar condições inadequadas de conservação e de padronização do produto, destacando-se, também, vários pontos críticos, como: a venda de gelo no lugar do produto; as diferentes denominações de tamanho; a comercialização de camarões sujos ou mal processados (CARVALHO et al., 2007). Deste modo, o camarão é tido como subpadrão, em decorrência da falta de controle maior no processamento e acondicionamento e transporte, comprometendo a qualidade do produto e dificultando a padronização e organização do mercado. Isto se dá pela pouca exigência do mercado interno com relação às questões de sanidade e ambiental, além da inoperância dos órgãos de fiscalização e controle da comercialização e distribuição. Em entrevistas com algumas empresas processadoras do Ceará, no entanto, foi constatado que elas não demonstram interesse em desenvolver novas formas de processamento do camarão, pois alegam que não compensa, em razão do elevado custo e de os preços não serem tão compensadores, tanto no mercado interno como no externo. Como já dispõem de canal de comercialização consolidado no segmento de mercado em que atuam, não querem correr riscos, pois, para produtos diferenciados, terão maior concorrência, em especial no mercado externo, o que necessitaria de estratégia de marketing agressiva para conquista de novos mercados.

Uma grande empresa localizada no APL do litoral Leste, no entanto, e outra situada no APL de litoral Oeste, estão, aos poucos, mudando esta realidade, ao procurarem padronizar e agregar valor ao camarão, lançando no mercado um produto diferenciado e de melhor qualidade.

Além disto, a Associação de Criadores de Camarão da Costa Negra - APL do Litoral Oeste, na tentativa de reconquistar o mercado externo, está procurando agregar valor ao produto, em decorrência da proteção conferida a uma grande área de produção de camarão concedida pelo registro de uma Indicação Geográfica (IG Costa Negra). O camarão da Costa Negra passa por um rigoroso processo de certificação de qualidade 
ambiental, pela produção do camarão orgânico, que tende a se expandir na região. Este passou a ter preferência no mercado europeu, sendo vendido acima de $40 \%$ do valor de venda do camarão produzido convencionalmente. Isto proporciona maior dinamismo a esse APL, tornando-se um fator positivo na direção de uma melhoria de capacitações produtivas e inovativas das empresas do APL. De fato, vários trabalhos desenvolvidos no âmbito da RedeSist mostram que o direcionamento da produção, especialmente como maior agregação de valor ao mercado interno, no caso dos países como o Brasil, traz melhores oportunidades de "inovatividade"

Porém, a participação das empresas dos APLs de cultivo de camarão do Ceará na cadeia internacional está fortemente associada à capacidade produtiva das empresas, já que elas não expressam avanços significativos na capacidade inovativa, ou seja, no desenvolvimento de novos produtos à base de camarão, de processos que envolvam gestão de qualidade e biossegurança, além da gestão ambiental, bem como no desenvolvimento de estratégias mais agressivas na busca de novos mercados e ativos comerciais (marca, novos canais de comercialização).

Pelas características expostas, observa-se que, mesmo com o dinamismo alcançado pelas empresas dos APLs no auge das exportações e sua participação em cadeia produtiva internacional, grande parte do valor gerado ao longo do processo de produção não é apropriado pelas produtoras/processadoras brasileiras, mas, sim, pelas grandes empresas importadoras, visto que o processamento mais sofisticado é realizado no exterior. Isto pode ser justificado pelo fato de o camarão comprado passar por processamento adicional nos países compradores, envolvendo custos maiores, especialmente com mão de obra e, portanto, ensejando maior renda. Com efeito, são importantes também o comando/coordenação desta cadeia e a forma de governança local dos APLs, o que será realizado na seção seguinte.

5. Entre estes trabalhos, ver Cassiolato e Szapiro (2003); Cassiolato e Lastres (2003) e Schmitz (2000, 2005).
4.5. Cadeias de produção e governança local nos APLs de cultivo de camarão do estado do Ceará

O dinamismo de determinado espaço territorial específico depende, em grande parte, da capacidade dos agentes que compõem tal espaço se organizarem com eficiência e interação, sendo que os formatos organizacionais e institucionais desempenham papel fundamental neste processo, pois contribuem para o estabelecimento de regras e padrões de comportamento. Da mesma forma, a estrutura de coordenação associada ao poder que determinados agentes detêm influencia fortemente o processo de aprendizado, a geração, disseminação e uso de conhecimentos, capacidade produtiva e inovativa, em um contexto territorial especifico e, consequentemente, maior dinamismo e competitividade.

Conforme visto na seção anterior, o acesso de produtores locais a mercados externos, na maioria dos casos, é condicionado à inserção em cadeias globais de produção controladas por grandes compradores internacionais. Assim, essa forma de inserção envolve uma complexa interação de instâncias locais e globais na organização e coordenação de suas atividades produtivas, demonstrando certo grau de assimetria nas relações de poder entre diferentes segmentos de agentes, sendo os principais estádios da cadeia de valor, em parte, controlados por agentes externos aos arranjos. Efetivamente, em ambos os arranjos analisados, os produtores locais detêm o poder sobre a organização e cooperação das atividades produtivas em termos locais, mas expressam pouca ou quase nenhuma influência em determinadas etapas da cadeia, quando se trata de processamento mais qualificado do camarão e de canais de comercialização. Algumas etapas mais simples de processamento e comercialização, porém, são organizadas e coordenadas por grandes empresas verticalizadas, localizadas nas regiões dos APLs, resultando no estabelecimento de relações hierárquicas entre essas e outros agentes locais e externos ou de intermediação de representantes das empresas distribuidoras nacionais e internacionais. 
Por conta desta assimetria, parte das pequenas e médias empresas não conseguem se apropriar dos benefícios obtidos ao longo do processo de produção e da distribuição desta, mesmo quando atuam no mercado doméstico, isto porque suas estratégias são, geralmente, sufocadas pelas grandes empresas locais. Estas empresas são verticalizadas e integradas, do ponto de vista do processo produtivo (larvicultura, fazendas de engorda e plantas de processamento) e estão, via de regra, ligadas a cadeias globais de produção. Essas empresas verticalizadas desempenham papel fundamental na coordenação local do APL. Grande parte das pequenas e médias depende delas para a compra de pós-larvas e comercialização de sua produção. Colaborando com esta discussão, Garcia et al. (2004) acentuam que estruturas produtivas heterogêneas e complexas podem ensejar elevadas assimetrias, resultando em desigualdade da capacidade de apropriação dos benefícios proporcionados pela aglomeração produtiva, ou seja, grande parte das pequenas e médias empresas locais não se apropria de parcelas mais significativas do valor gerado ao longo do processo de produção, distribuição e comercialização, mesmo quando atuam no mercado doméstico.

Considerando-se o APL do litoral Leste, por exemplo, existiu, até 2008, um sistema integrado de produção - subcontratação de pequenas empresas, as quais recebem das empresas integradas insumos, como ração, fertilizantes e assistência técnica, além de se responsabilizar também pela despesca e transporte do camarão. Em troca, as pequenas empresas se comprometiam a fornecer a produção e a aceitar a classificação do camarão e o preço estabelecido pela empresa integradora. Com a queda das exportações, este sistema se desfez, mas a empresa ainda continuou exercendo certa governança local.

No arranjo produtivo de cultivo de camarão do litoral Oeste, a estrutura de governança local difere um pouco do APL do litoral Leste, primeiro, pela não existência de um sistema integrado de produção, até mesmo pela predominância de médias empresas e, segundo, pela maior concentração de empresas compradoras/processado- ras. Destaca-se também neste APL a importância do papel desempenhado pelos agentes de intermediação/exportação, atuantes na intermediação de contrato das empresas processadoras da região com as grandes redes de compra nacionais e internacionais, em particular, da Espanha e da França, pois há uma empresa de grande porte que coordena o APL e a Associação dos Criadores de Camarão da Costa Negra (ACCN). Essa empresa atua no mercado com marca própria, possui pontos exclusivos de comercialização fora do arranjo, e foi a primeira a receber o selo da Indicação Geográfica - Camarão da Costa Negra, além do selo de camarão orgânico; portanto, exerce influência no arranjo produtivo, podendo, inclusive, induzir outras empresas locais a adotarem tais processos. Há, também, empresas de processamento que desempenham papel importante nos APLs, pois são responsáveis pela ligação entre as empresas locais com o mercado interno e externo.

Deste modo, nos APLs de cultivo de camarão, as assimetrias de poder na coordenação dos sistemas de produção, geralmente, são focalizadas nas relações entre produtores locais, empresas processadoras e os compradores nacionais e internacionais. Estas se refletem no controle de etapas específicas da cadeia produtiva, comercialização, processamento e distribuição por parte das grandes redes nacionais e internacionais, que exercem a governança da cadeia. Isto limita a ação de produtores locais com relação ao controle de etapas da cadeia produtiva e também o papel e a importância de variados segmentos de agentes locais na coordenação dos APLs. Assim, a forma com as empresas dos APLs se inserem no mercado influencia de forma significativa sua competitividade e dinamismo, pois os produtores dos APLs ocupam posição menos favorecida na cadeia global do segmento, sendo, portanto, o seu elo mais frágil. Assim, ambos os APLs apresentam boa capacidade tecnoprodutiva, porém, ainda são pouco dinâmicos, uma vez que são dependentes dos grandes compradores nacionais e internacionais que deixam pouco espaço para avanços mais significativos em termos de agregação de valor ao produto e conquista de ativos comerciais. 


\section{Conclusão}

A inserção das empresas dos APLs do cultivo de camarão do Ceará no mercado externo ocorreu por meio de suas integrações a cadeias de produção global do segmento, em que os agentes exportadores tiveram papel fundamental. Assim, as empresas dos arranjos analisados, por estarem inseridas em cadeias de produção, apresentam dificuldades para dominar ativos essenciais do segmento, em especial os ativos tecnológicos e comerciais, de propriedade das grandes importadoras. Neste caso, essa configuração influencia fortemente a capacidade desses arranjos na busca de vantagens competitivas dinâmicas e sustentáveis, visto que os determinantes externos se sobrepõem aos internos. Isso porque, embora se verifique aprendizado voltado para o aumento da capacidade produtiva, as empresas desses arranjos têm dificuldades de gerar capacitações que transcendem a esfera da produção, como na busca de ativos comerciais de maior agregação de valor ao produto. Além disto, a inserção nesta cadeia não permite que as empresas produtoras/ processadoras se apoderem do valor agregado ao longo do processo de produção. Com efeito, as empresas dos arranjos não se apropriam dos benefícios gerados, visto que o processamento adicional (ou seja, o mais sofisticado) do camarão é realizado por empresas de fora do País.

As ligações com o mercado externo, no entanto, em ambos os APLs, representam uma parcela pouco significativa das vendas totais, pois, pela perda de competitividade, os produtores se voltaram para o mercado interno, embora inicialmente com muitas dificuldades por não possuírem canais de comercialização consolidados. Conclui-se, todavia, que grande parte das empresas, ao direcionarem a produção para o mercado interno, não proporcionaram maior desenvolvimento na agregação de valor ao produto, visto que o camarão continuou sendo vendido, na sua maioria, in natura, sem padronização e sem maior controle sanitário. No entanto, observa-se que em ambos os APLs há empresas que estão procurando mudar essa realidade, com destaque para uma grande empresa do APL do Litoral Oeste que detém os selos da IG do camarão Costa Negra e de qualidade ambiental, além de sua própria marca, lançando no mercado produtos diferenciados e de melhor qualidade.

Da mesma forma, a Associação de Criadores de Camarão da Costa Negra - APL do Litoral Oeste, está realizando um trabalho junto aos outros produtores da região para a adesão ao selo da IG e de certificação de qualidade ambiental, bem como para a produção do camarão orgânico, na tentativa de reconquistar o mercado externo. Tornando-se, portanto, um fator positivo na direção de melhoria de capacitações produtivas e inovativas das empresas deste APL.

A estrutura de governança nos arranjos produtivos de cultivo de camarão é expressa de forma hierarquizada. As relações entre os principais elos da cadeia produtiva são do tipo vertical, em que o seu controle está centrado em um núcleo reduzido de empresas locais, nacionais e internacionais. Assim, as relações de poder são assimétricas ao longo da cadeia produtiva, em que os principais estágios da cadeia de valor são apreendidos em grande parte por agentes externos. Essa assimetria nas relações entre instâncias locais e externas de coordenação ocorre pela integração de algumas grandes empresas dos arranjos às cadeias globais de produção, sendo necessário, portanto, um estudo aprofundado sobre a forma de subordinação de tais empresas aos compradores nacionais e internacionais.

\section{Referências bibliográficas}

ABCC. O Censo da carcinicultura nacional em 2011. Revista Associação Brasileira de Criadores de Camarão, v. 15, n. 1 p. 24-28, 2013a.

O censo da carcinicultura nacional em 2011. Disponível em: <http://www.abcc.com.br>. Acesso em: 10 mai. 2012.

Estatísticas ABCC - Estatísticas do setor pesqueiro e da carcinicultura brasileira. Disponível em: $<$ http://www.abcc.com.br>. Acesso em: 10 mai. 2013b. BRACARENSE, N. M. e BOTELHO, M. R. A inserção em cadeias globais de valor: o caso da aglomeração 
moveleira de São Bento do Sul. Ensaios FEE, Porto Alegre, v. 30, n. 2, 2009.

BRITTO, J. e STALLIVIEIRI, F. Inovação, cooperação e aprendizado no setor de software no Brasil: análise exploratória baseada no conceito de arranjos produtivos locais (APLs). Economia e Sociedade, Campinas, v. 19, n. 2-29, p. 315-358, ago. 2010.

CARVALHO, R. A. P. L. F., RUIVO, U. E. e ROCHA, I. Mercado Interno: situação e oportunidades para o camarão brasileiro. Panorama da Aquicultura, mai./jun. 2007.

CASSIOLATO, J. E. e SZAPIRO, M. Uma caracterização de arranjos produtivos locais de micro e pequenas empresas. In: LASTRES, H. M. et al. (Orgs.). Pequenas empresas: cooperação e desenvolvimento local. Rio de Janeiro: Relume Dumar, p. 35-50, 2003.

COSTA, E. e SAMPAIO, Y. Geração de empregos diretos e indiretos na cadeia produtiva do camarão marinho cultivado. Rev. Economia Aplicada, v. 8, n. 2, p. 1-19, abr./ jun., 2004.

FAO. Fisheries and Aquaculture Information and Statistics Service. Global Aquiculture Produções - 19502011. FAO. 2013. Disponível em: < http://www.fao.org/ statis>. Acesso em: 06 jun. 2013.

. Estudo Mundial de Pesca y la Aquicultura, Parte I e II. Exame mundial dela pesca e la acuicultura, 2012. Disponível em: <http://www.fao.org>. Acesso em: 6 abr. 2013.

FILOSE, J. El mercado del camarón en EEUU: Estado actual y perspectivas para mediano y largo plazo (Parte II). INFOPESCA Internacional, n. 39, p. 10-14, jul./set. 2009.

GARCIA, R., MOTTA, F. G. e AMARAL NETO, J. Uma análise das características da estrutura de governança em sistemas locais de produção e suas relações com a cadeia global. Gest. Prod. São Carlos: v. 11, n. 3, set./dez. 2004.

GEREFFI, G. The organization of buyer-driven global commodity chains: how U.S. retailers shape overseas production netwoorks. In: GEREFFI, G. e KORZENIEWICZ, M. (Ed.). Commodity chains and global capitalism. Westport: Praeger, p. 95-122, 1994.

. Internacional trade and industrial upgrading in the apparel commodity chain. Journal of International Economs, v. 48, n. 1, 1999.

GEREFFI, G., HUMPHREY, J. e STURGEON, T. The governance of global value chains. Review of International Economy, v. 12, n. 1, p. 78-104, 2005.
GIL, A. C. Métodos e Técnicas de Pesquisa Social. 6. ed. São Paulo: Atlas, 2008.

GLOBEFISH. The shrimp market is on the rise despite the difficult global economic, dez. 2012. Disponível em: $<$ www.globefish.org/upl/Publications/files/GSH April_2011.pdf>. Acesso em: 8 abr. 2013.

HUMPRHEY, J. e SCHMITZ, H. Governance and upgrading: linking industrial cluster and global value chain research. IDS Eorking Paper, n. 120, Sussex, nov, 2000 .

Governance in global value chains. In: SCHMTZ, H. (Ed.). Local enterprises in the global economy: Issues of values of governance and upgrading Cheltenham: Edward Elgar, 2004.

MADRID, R. M. Brasil e o Mercado Americano de camarões. Panorama da Aquicultura, São Paulo, p. 53-55, jul./ago. 2006.

MADRID, R. M. e WURMANN, C. O futuro da carcinicultura brasileira. Revista da $A B C C$, ano XII, n. 2, p. 40-42, jun. 2011.

NAVAS-ALEMAN, L. The impact of operating in multiple value chains for upgrading. World Development, v. 39, n. 8, p. 1386-1397, 2011.

NEILAND, A. E. et al. Shimp aquicultura: economic perspectives for policy development. Marine Policy, v. 4, n. 25, p. 265-279, 2001.

PIETROBELLI, C. e RABELLOTTI, R. Global value chains meet innovation systems: are there learning opportunities for developing countries? World Development, v. 39, n. 7, p. 1261-1269, 2011.

ROCHA, I. Impactos socioeconômicos e ambientais da carcinicultura brasileira: Mitos e verdades. Revista da $A B C C$, ano 7, n. 4, p. 29-36, dez. 2006.

- Análise da balança comercial, das potencialidades dos entraves confrontados pelo setor aquícola brasileiro, com destaque para a carcinicultura. Revistas da ABCC, ano XIV, n. 2, jun. 2012.

. Analise da produção e do mercado interno e externo do camarão cultivado, 2011. Disponível em: < http:// www.abccam.com.br.pdf>. Acesso em: 2 abr. 2013.

REDESIST - Rede de Pesquisa em Sistemas e Arranjos Produtivos e Inovativos Locais - Glossário, 2005. Disponível em: <http://www.redesist.ie.ufrj.br>. Acesso em: 20 jul. 2013.

SCHMITZ, H. e NAVID, K. Clustering and industrialization: introduction. World Development, v. 27, n. 9, p. 1503-1514, 1999. 
SCHMITZ, H. e KNORRINGA, P. Learning from global buyers. IDS WorgingPaper, n. 100 Brighton; University of Sussex, 2000.

SCHMITZ, H. Aglomerações produtivas locais e cadeias de valor: como a organização das relações entre empresas influencia o aprimoramento produtivo. In: LASTRES. H. M. et al. (Orgs.) Conhecimento, Sistema de Inovação e Desenvolvimento. Rio de Janeiro: Ed. UFRJ/ Contraponto, 2005, p. 321-345.

SECEX/MDIC. Secretaria de Comércio Exterior do Ministério do Desenvolvimento, Indústria e Comércio Exterior. Disponível em: <http://aliceweb2.mdic.gov. br/> . Acesso em: 05 mai. 2013.

SILVA, J. L. e SAMPAIO, L. M. B. Eficiência, gestão e meio ambiente na carcinicultura do Rio Grande do Norte. Rev. Econ.Sociol. Rural. Brasília: v. 47, n. 4, p. 883902, 2009.
SILVA, J. L. M. e MARTINS, J. S. Competitividade e parcela de mercado: uma análise do Constant market share para o camarão brasileiro. BNB/Documentos Técnicos Científicos, v. 43, n. 01. jan./mar. 2012.

SOUZA JUNIOR, J. F., CARIO, S. A. F. e FERNANDES, R. L. Avaliação da participação das micro e pequenas empresas (MPEs) do segmento de confecções de Santa Catarina no mercado externo: características, vantagens e dificuldades de inserção. A Economia em Revista, v. 19, n. 2, dez. 2011.

SUZIGAN, W., GARCIA R. e FURTADO, J. Estrutura de Governança em arranjos produtivos locais ou sistemas lociais de produção. Gest. Prod., São Carlos, v. 14, n. 2, p. 425-439, mai./ago. 2007.

VARGAS, M. A. Forms of governance, learning mechanisms and upgrading strategies in the Tobacco cluster in Rio Pardo Valley, Brasil. Institute of Development Studies, Worpaper 125, 2001. 